\title{
DEEP EXPLORATORY TEST HOLES \\ FOR WASTE REPOSITORY INVESTIGATIONS
}

T. F. Lomenick

September 14, 1976

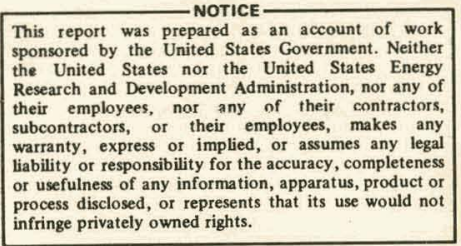

This document was initially prepared to inform UCC-ND management and technical staff and may contain information which is fragmentary and of limited scope. As an internal document, it does not conform to UCC-ND's standards for forma 7 reports receiving TID-4500 category distribution.

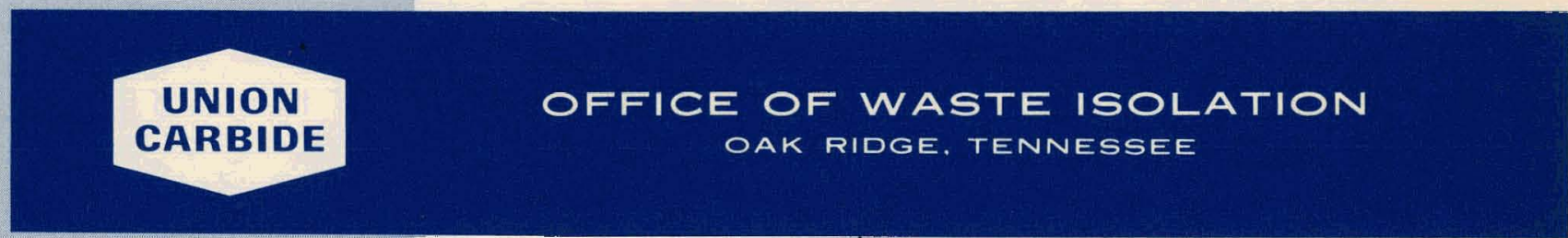

prepared for the U.S. ENERGY RESEARCH AND DEVELOPMENT ADMINISTRATION under U.S. GOVERNMENT Contract W-7405 eng 26 


\section{DISCLAIMER}

This report was prepared as an account of work sponsored by an agency of the United States Government. Neither the United States Government nor any agency Thereof, nor any of their employees, makes any warranty, express or implied, or assumes any legal liability or responsibility for the accuracy, completeness, or usefulness of any information, apparatus, product, or process disclosed, or represents that its use would not infringe privately owned rights. Reference herein to any specific commercial product, process, or service by trade name, trademark, manufacturer, or otherwise does not necessarily constitute or imply its endorsement, recommendation, or favoring by the United States Government or any agency thereof. The views and opinions of authors expressed herein do not necessarily state or reflect those of the United States Government or any agency thereof. 


\section{DISCLAIMER}

Portions of this document may be illegible in electronic image products. Images are produced from the best available original document. 
This report was prepared as an account of work sponsored by the United States Government. Neither the United States nor the Energy Research and Development Administration, nor any of their employees, nor any of their contractors, subcontractors, or their employees, makes any warranty, express or implied, or assumes any legal liability or responsibility for the accuracy, completeness or usefuiness of any information, apparatus, product or process disclosed, or represents that its use would not infringe privately owned rights. 


\title{
DEEP EXPLORATORY TEST HOLES \\ FOR WASTE REPOSITORY INVESTIGATIONS
}

\author{
T. F. Lomenick
}

Since 1970 a total of nine deep boreholes have been drilled by $A E C$ and its successor agency, ERDA, with in six different study areas of Kansas and New Mexico to provide geologic and hydrologic data that would aid in establishing the utility of the areas for the storage of radioactive wastes. The drilling of the first three wells was directed by the Union Carbide Corporation- Nuclear Division through the Oak Ridge Operations Office of AEC-ERDA, while the last two drillings were directed by the Sandia Corporation through the Albuquerque Operations Office of ERDA. In addition, certain geophysical logs, rock cores, and hydrologic data were acquired during the drilling of oil and gas test holes by private firms within some of the study areas.

As seen in Figure 1, the deep boreholes are all located within the Permian Salt Basin and in particular, in central and western Kansas and southeast New Mexico. Pertinent data regarding the exact location, depth, geophysical logging and other properties for each borehole are summarized in Table 1.

Boreholes designated as UCCND-AEC \#1 and UCCND-AEC \#2 were drilled in the late summer and fall of 1970 at the so-called Lyons, Kansas study area. The first hole was cored for its entire depth of $1300.8^{\prime}$ while only the salt section from $739^{\prime}-1099.6^{\prime}$ was cored in the second hole. Both holes were hydraulically tested at the critical horizons above and below the salt, and extensive geophysical logging of the open boreholes was accomplished. Also within the Lyons area, a specific suite of geophysical logs was acquired from a private firm that reopened and tested a 3502' deep oil and gas hole, known as Dressler \#1, during the fall of 1970. Geophysical logs and hydraulic data were also acquired in November 1970 for a deep borehole, Stockham \#2, that was drilled by private interest in the Lyons area in search of 011 and gas. Later, in October 1971, another privately drilled oil and gas test hole, Wright \#1, provided cores, logs and hydraulic data on the same area. The cores, logs and hydraulic tests from these boreholes all showed the salt deposits in the area to be structurally and stratigraphically sound; however, because of some concern over nearby mining operations and the rather high density of boreholes within the area, coupled with some negative actions by state officials and other parties, studies in the Lyons area were suspended; other areas were subsequently investigated to the north and to the west or Lyoins.

In May of 1972, UCCND-AEC \#3 was drilled in northern Lincoln County, Kansas to a depth of $1100^{\prime}$ to test the thickness of salt and to obtain other geologic data. Within the same month, UCCND-AEC \#4 was drilled to a depth of $1275^{\prime}$ in 
the southern part of. Lincoln County to test another area. Later on in the fall of 1972, the fourth study area in Kansas was penetrated and tested with a borehole to a depth of $2450^{\prime}$. Hydraulic testing and geophysical logging were conducted in all three boreholes. For the two study areas in Lincoln County, it was concluded, after assessing the core data and other information, that the salt was thinner than anticipated even though other geologic and hydrologic factors were extremely favorable. The only apparent negative aspect of the western Kansas area was the abnormally high concentrations of clay in the salt. Thus, even though the rock salt deposits in all of these areas probably would have proven to be quite capable of containing any emplaced wastes, each study area processed some undesirable, but not necessarily unacceptable traits which prompted the continued search for "better sites."

UCCND-AEC boreholes \#7 and \#8 were drilled during 1974 to test the first of two study areas in southeast New Mexico. Previously, in 1973, some cores and geophysical logs were procured from the owner of a nearby deep oil and gas test well known as Badger Unit Federal \#1. The geologic and hydrologic data generated from these borings suggested that the area might prove to be suitable for a pilot plant repository. However, a later exploratory hole, Sandia-ERDA \#6, revealed the presence of a localized "flow structure" in the salt deposits that cast some doubt as to the worthiness of the area. Subsequentiy, another study area was selected for investigations a few miles to the southwest of the previous one. The first borehole, Sandia-ERDA \#9, to test this area showed favorable subsurface conditions. Obviously, though, the utility of this latest study area for waste storage can only be ascertained after several more deep drill tests are made within it.

In summary, a significant number of deep boreholes has been drilled within the Permian Basin to investigate subsurface geologic conditions for waste storage utility. As these investigations have yet to reveal a single "acceptable site," it is quite clear that many deep test holes can be expected to be drilled and several study areas "abandoned" before specific sites for pilot plants and/or for permanent repositories are selected. Indeed, this has been the case in the Permian Basin, and there is little reason to believe that similar patterns would not prevail for other salt deposits and even for non-saline rock formations that are undergoing investigations as waste storage repositories. These time-consuming and, at times, seemingly unproductive iterations are due in part to the general lack of detailed knowledge of the important characteristics of rocks in the subsurface that can only be obtained by drilling closely-spaced boreholes with in the area of interest. In addition, the long-term nature of the problem which makes it imperative that the wastes be contained for periods of up to hundreds of thousands of years, requires an unprecedented amount of detail in the investigative work. 


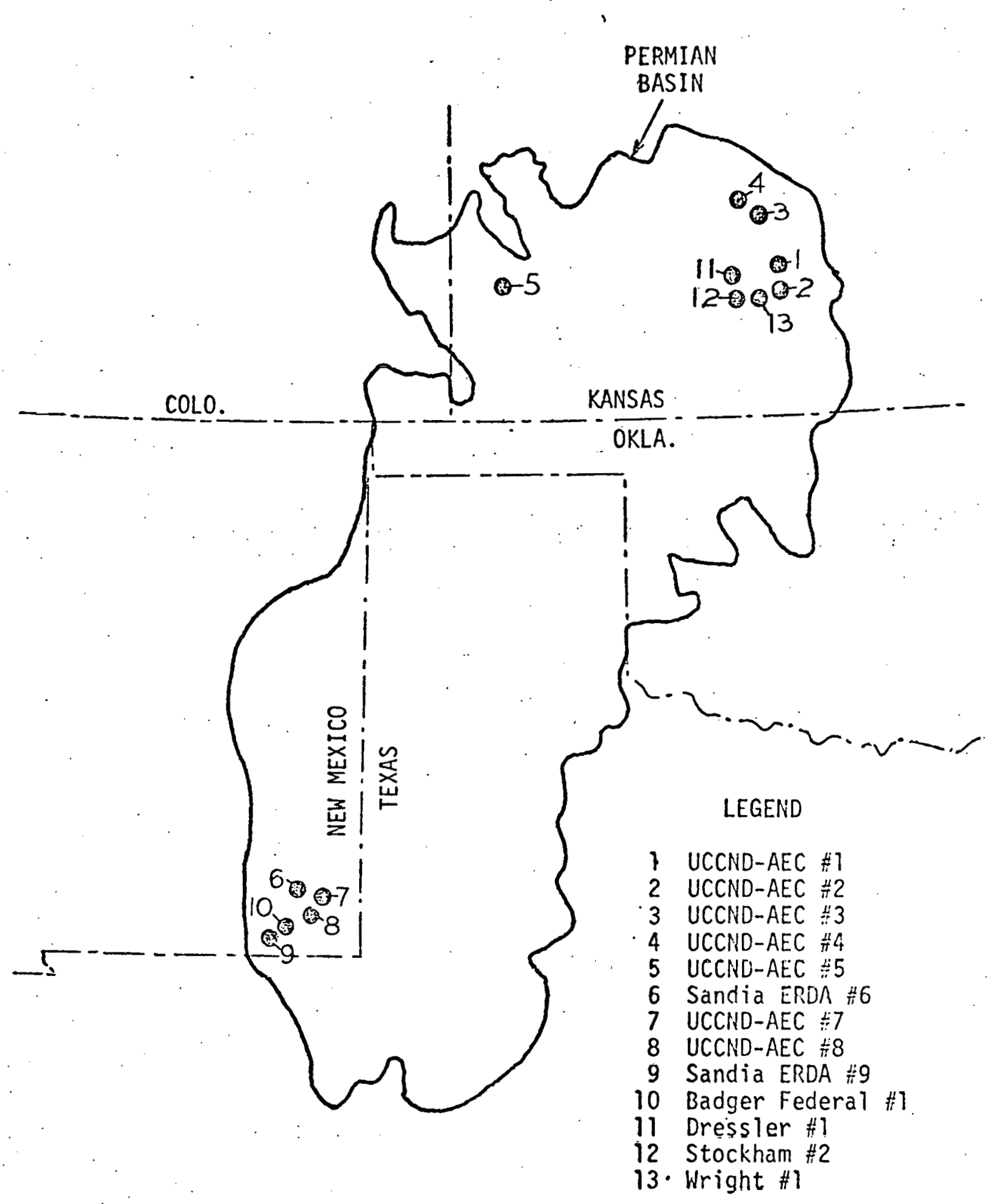

Figure 1. Location of Deep Exploratory Boreholes in the Permian Basin 
TabIe 1 - DEEP EXPLORATORY TEST HOLES FOR RADIOACTIVE WASTE REPOSITORIES

\begin{tabular}{|c|c|c|c|c|c|c|c|c|c|}
\hline ¿ELL IOENTIFICATION AN & D LOCATIOH. & DATE COMPLE & ETED & $\begin{array}{r}\cdot \\
\text { TOTA } \\
\end{array}$ & & $\begin{array}{c}\text { CORED } \\
\text { INTERNAL } \\
\text { Coepth - Fe } \\
\end{array}$ & LOGS & $\begin{array}{c}\text { HYDRAULIC TEST } \\
\text { HORIZOHS } \\
\text { (Cepth-Feet) } \\
\end{array}$ & 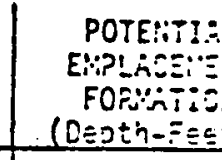 \\
\hline 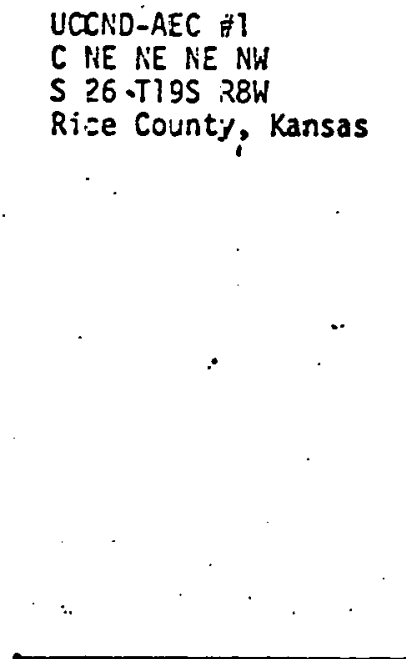 & $\cdot$ & 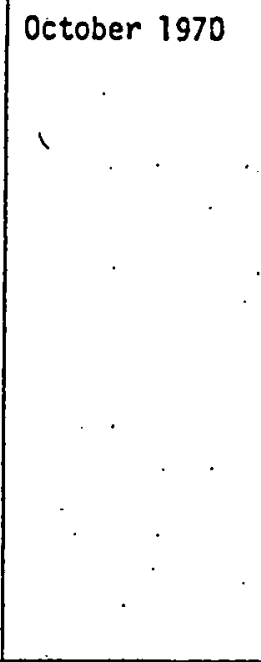 & 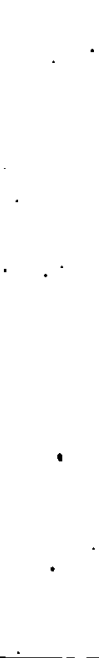 & ${ }^{1300.8^{\prime}}$ & & $\begin{array}{l} \\
\\
. \\
. \\
\cdot \\
\cdot . \\
.\end{array}$ & $\begin{array}{l}\text { Gamma Ray - Neutron } \\
\text { Sidewall Neutron Po- } \\
\text { rosity } \\
\text { Oual Induction - } \\
\text { Laterolog } \\
\text { Microlaterolog . - } \\
\text { Microlog (w/cali- } \\
\text { per) } \\
\text { Borehole Comp. Sonic } \\
\text { Comp. Fm. Density } \\
\text { Compressional Ampli- } \\
\text { tude } \\
\text { Compressional Shear } \\
\text { Amplitude } \\
\text { Variable Density } \\
\text { High Resolution Temp. } \\
\text { Caliper. } \\
\text { 3-dimensional Veloc- } \\
\text { ity }\end{array}$ & $\begin{array}{l}236^{\prime}-321^{\prime} \\
802^{\prime}-1300.8^{\circ}\end{array}$ & $\begin{array}{l}\text { Hutchinson } 5 \\
815^{\circ}-1084 . \\
.\end{array}$ \\
\hline
\end{tabular}




\begin{tabular}{|c|c|c|c|c|c|c|}
\hline EILL SOENTIFICATION AND LOCATION & DATE COMPLETED & $\begin{array}{c}\text { TOTAL DEPTH } \\
\text { (Feet) }\end{array}$ & $\begin{array}{c}\text { CORED } \\
\text { INTERNAL } \\
\text { (Depth - Feet) }\end{array}$ & LOGS & $\begin{array}{l}\text { HYDRAULIC TEST } \\
\text { HORIZONS } \\
\text { (Depth-Feet) }\end{array}$ & 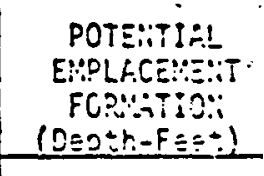 \\
\hline $\begin{array}{l}\text { Oressler } \\
\text { C NE/4 NE/4 NE/4 } \\
5.27 \mathrm{TISS} R 8 \mathrm{~h} \\
\text { Rice County, Kansas }\end{array}$ & November 1970 & $3502^{\prime}$ & None & $\begin{array}{l}\text { Laterolog Gamma Ray - } \\
\text { Neutron } \\
\text { Borehole Compensated } \\
\text { Sonic (w/Caliper) }\end{array}$ & None & $\begin{array}{l}\text { Wellington Se:t } \\
811 !-1057\end{array}$ \\
\hline $\begin{array}{l}\text { Stockham \#2 } \\
\text { C ME/4 MiN/4 NE/4. } \\
\text { S } 34 \text { T } 195 \text { REW } \\
\text { Rice County. Kansas } \\
.\end{array}$ & November 1970 & 3467 & None & $\begin{array}{l}\text { Laterolog Gamma Ray - } \\
\text { Neutron } \\
\text { Borehole Compensated } \\
\text { Sonic (w/caliper) } \\
\text { Formation Density. }\end{array}$ & $\begin{array}{l}3378^{\prime}-3388^{\prime} \\
3440^{\prime}=3466^{\prime}\end{array}$ & $\begin{array}{l}\text { Wellington Sal1 } \\
775^{\circ}-1062^{\circ}\end{array}$ \\
\hline 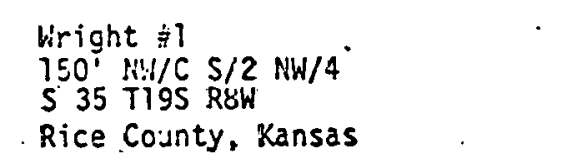 & October 1971 & $3583^{\prime}$ & $\begin{array}{l}1415^{\prime}-1455^{\prime} \\
2564^{\prime}-2604^{\prime} \\
2783^{\prime}=2823^{\prime} \\
3003^{\prime}=3043^{\prime}\end{array}$ & $\begin{array}{l}\text { Radiation - Guard } \\
\text { Acoustic Velocity } \\
\text { Fracture Finder/Micro- } \\
\text { Seismogram }\end{array}$ & $\mid \begin{array}{l}1416^{\prime}-1455^{\prime} \\
2565^{\prime}=2604^{\prime} \\
2784^{\prime}=2823^{\prime} \\
3004^{\prime}-3043^{\prime}\end{array}$ & $\begin{array}{l}\text { Wellington Sal } \\
759^{\circ}-1036^{\circ}\end{array}$ \\
\hline $\begin{array}{l}\text { UCCNO-AEC, } 3 \\
150^{\prime} S 750 \cdot W N=/ 4 \text { SE/4 } \\
\text { S22 TI3S RBW } \\
\text { Lincoin County, Kansas }\end{array}$ & June 1972 & 1100 & $\begin{array}{c}750^{\circ}=1000^{\prime} \\
\cdots\end{array}$ & $\begin{array}{l}\text { Radiation - Guard } \\
\text { Density } \\
\text { Comp. Acoustic Veloc- } \\
\text { ity } \\
\text { Caliper. }\end{array}$ & $\begin{array}{l}225^{\circ}=380^{\prime} \\
967^{\prime}=1100^{\prime} \\
409^{\circ}=1100^{\prime}\end{array}$ & $\begin{array}{l}\text { Wellington Sal } \\
969^{\circ}-1096^{\circ}\end{array}$ \\
\hline 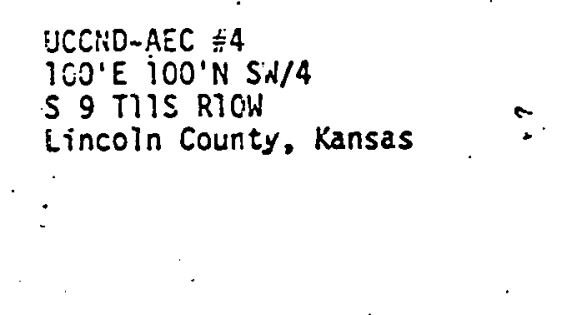 & June 1972 & 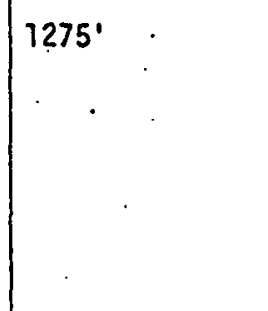 & $\begin{array}{l}990^{\circ}-1217^{\prime} \\
.\end{array}$ & $\begin{array}{l}\text { Radiation - Guard } \\
\text { Density } \\
\text { Comp. Acoustic Veloc- } \\
\text { ity } \\
\text { Electric } \\
\text { Caliper } \\
\text { Self Potential Resis- } \\
\text { tivity }\end{array}$ & $\mid \begin{array}{l}408^{\prime}-573^{\circ} \\
1186^{\circ}-1275^{\prime} \\
650^{\circ}=1275^{\circ}\end{array}$ & $\begin{array}{l}\text { Wellington Sal } \\
1020^{\circ}-1186^{\circ}\end{array}$ \\
\hline . & . & . & $:$ & . & & $a$ \\
\hline
\end{tabular}




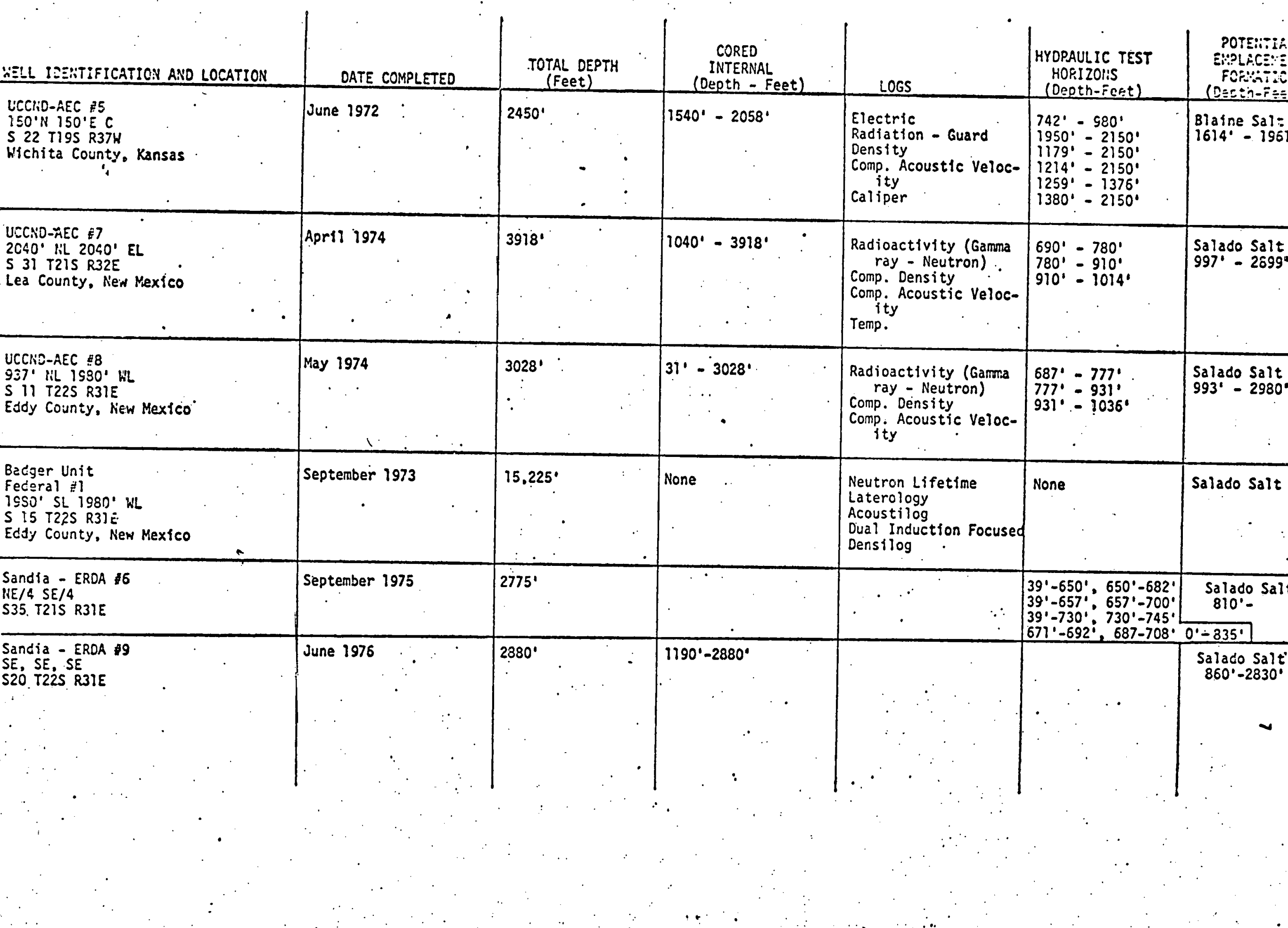


Office of Waste Isolation

J. M. Asher

K. K. Aydelotte

R. Bl umberg

A. L. Boch

G. D. Brunton

E. B. Cobb

P. D. Fairchild

R. B. Laughon

T. F. Lomenick

R. S. Lowrie

S. C. Matthews

L. L. McCauley

W. C. McClain

J. R. Palmer

A. S. Quist

W. K. Russell

C. D. Zerby

OWI Records - RC

OWI Records - 5

Y-12 Plant

H. I. Cobert

J. D. Griffin 